\title{
Information support of the Eurasian integration: The image of the EAEU in the mainstream media of the member states
}

\section{Olga Vikhrova ${ }^{1}$}

Lomonosov Moscow State University, Russia

Aleksandr Hradziushka

Belarusian State University, Belarus

Olga Muravyova

Eurasian National University, Kazakhstan

Marina Alekyan

Russian-Armenian University, Armenia

Nazira Akhmedova

K. Karasaev Bishkek State University, Kyrgyzstan

To cite this article: Vikhrova, O., Hradzhiushka, A., Muravyova, O., Alekyan, M., \& Akhmedova, N. (2021). Information support of the Eurasian integration: The image of the EAEU in the mainstream media of the member states. World of Media. Journal of Russian Media and Journalism Studies 2. DOI: 10.30547/worldofmedia.2.2021.4

\begin{abstract}
Mass media, as the main tool for information support of integration processes of any regional economic association, are designed to ensure the internal stability of the Eurasian Economic Union, without which it is impossible to strengthen its position on the international stage. In this article, through the analysis of news content of the mainstream broadcasters and print and online media of the member states, it was identified, which thematical components of the image of the Eurasian Economic Union, affecting the perception of the young regional association by population, and to what extent they are currently available to mass audience in Russia, Belarus, Armenia, Kazakhstan, and Kyrgyzstan.

The study showed that the information support of the Eurasian integration, unregulated for five years and transferred to the management of the media themselves, led to that the main topics as of Q4 2019 were: meetings of the

\footnotetext{
${ }^{1}$ Corresponding author:

Olga Vikhrova, Lomonosov Moscow State University, Faculty of Journalism, 9, Mokhovaya st, Moscow, Russia.

Email: financialliteracymsu@gmail.com
} 
leaders of the EAEU states, legislative regulation, as well as the prospects for the development of the relations between the Union countries. At the same time, the vast majority of materials are depersonalized information, rather than personalized materials that illustrate the benefits of integration for the public. All this leads to the formation of information apathy to the integration issues both in society and on the part of the journalists themselves.

\section{Keywords}

Eurasian Economic Union, Eurasian integration, information policy of the EAEU, image of the EAEU, Eurasian integration in mass media.

\section{Introduction}

In the $21^{\text {st }}$ century, the global geopolitical field is characterized not only by globalization and integration trends but also by the ever-increasing competition of the certain states in order to expand the spheres of their economic and political influence. To consolidate their dominant positions, the countries actively use all available mechanisms of influence on domestic and foreign audiences, and mass media is one of the most important tools to achieve the assigned tasks.

However, mass media demonstrate their efficiency not only in terms of providing information support to the policy of states in the implementation of their sovereign interests but also when it comes to information support to the integration processes of regional economic blocs. They are a key element of the system of forming the image of the integration associations, which directly affects the implementation of both the interests of the unions and each of the countries individually on the global stage.

'Strengthening the international legitimacy of the EAEU is of great importance for the national interests of the Russian Federation in the field of foreign policy, and the coordinated foreign policy of the Union plays an important role in terms of countering internal and external threats to the Eurasian integration project as a whole' (Meshkova, 2019). However, increasing the effectiveness of countering external and internal threats, as well as increasing the international legitimacy of the EAEU, is possible only under the condition of constant and strategically built information support for Eurasian integration.

Stressing the importance of professional journalism in ensuring information security on the post-Soviet territories (Osavelyuk, 2016; Temirbulatov, 2013; Vartanova, 2019) and the key role of mass media in the Eurasian integration (Galtsina, 2017; Popov, 2015; Vikhrova, 2020), researchers note that without involving citizens in the agenda of the Eurasian integration, the governments 
will not be able to ensure the necessary support. In addition to the measures taken at the level of the EEC in terms of ensuring information security as digital security of the integration association from external threats at the level of information and communication technologies (Vikhrova, 2020), the Eurasian integration, like any other significant political or economic project, requires constant and professional information support. As early as in 2015, the director of the Eurasian Communication Center Alexey Pilko stressed that it is the mass media that should act 'as the engine of the Eurasian integration, using the entire arsenal of modern multimedia journalism', and that its development depends on them ${ }^{2}$.

Saadat Asanseitova, Deputy Director of the Integration Development Department of the Eurasian Economic Commission, confirms this point: 'The Eurasian integration provides more and more benefits for businesses and citizens of the EAEU countries. The relevance of the systematic and professional coverage of innovations in supranational legislation is growing, and in this context, it is difficult to overestimate the role of mass media'³.

\section{Scientific novelty and research methodology}

The role of mass media in the formation and activation of integration processes of the regional associations has been the object of close interest of foreign scientists for more than two decades (Bijsmans \& Altides, 2007; Clement, 2015; De Vreese \& Kandyla, 2011; Fetoshi, 2017; Menéndez Alarcón, 2010; PolonskaKimunguyi \& Kimunguyi, 2011, etc.). Arben Fetoshi notes that the role of media in the European Integration process is irreplaceable both in preserving internal cohesion of the EU, and regarding civic awareness and mobilization in enlargement countries', explaining that the Western researchers have focused on the relationship of mass media, politics and public, since the future of the European project depends on this triangle (Fetoshi, 2017).

Antonio V. Menéndez Alarcón notes that 'most opinions of the EU are influenced by stories that circulate among the public and images that can be characterized as symbolic experiences, which are mostly diffused by the media'. He concludes that 'mass media can shape public views and contribute towards creating a framework of reference of the European Union'.

${ }^{2}$ PILKO, A. Stop talking about integration. RIA Novosti, $28^{\text {th }}$ May, 2015. Available from: https://ria.ru/20150526/1066585015.html

${ }^{3}$ Eurasian Economic Commission (2019). The EEC is interested in greater transparency of integration. Available from: http://www.eurasiancommission.org/ru/ nae/news/Pages/29-04-2019-4.aspx 
Under these conditions, M. Latzer and F. Sauerwein emphasize that policy jointly bears the responsibility for the emergence of the European public sphere and the democratization of the European Union - through institutional reforms and rapid response, mass media - through attention, criticism and control, and citizens - through interest and participation (Latzer, 2006). At the same time, the researchers define mass media as a connecting element and infrastructure that determines the rules and conditions of the processes of 'transnationalisation and Europeanization' of the sovereign EU states in the context of a growing number of cross-national disagreements (Latzer, 2006). 'Media influence on support to the European integration by society, as well as on building of a European identity is an undeniable fact, recognized by the researchers in the field of communication', V. Triga and K. Vadratsikas (2016-2018) emphasize, analyzing the impact of the EU media representation on the population of the EU countries.

There are some disagreements among the researchers regarding the formation of the so-called European identity, as well as the definition and functioning of the European public sphere. For example, Clement (2015) believes that despite the creation of pan-national governing structures in Europe, this did not affect significantly the perception of the citizens of their identities, and Polonska-Kimunguyi and Kimunguyi (2011) note that the European identity concept was introduced 'top - down', which forms the relation of the integration processes with the will of the political elites, but not with the desire of people. Clement (2015) and Kandyla and De Vreese (2011) emphasize that the current supranational public sphere lacks such key components as linguistic homogeneity and common media. However, they are sure that the formation of a European public sphere can be achieved with the help of 'increased presence of European issues and actors in the national news media and the evaluation of those from a European rather than a national perspective' (Kandyla \& De Vreese, 2011).

However, despite the above differences, E. Eriksen formulates the most important function of mass media in the European space: they allow not only information to reach every EU resident, regardless of social status, language or location, but also to get feedback - 'hearing the voice of Europe', to adjust the integration process of certain countries (Eriksen, 2000).

In the European Union, where since 1995 under the leadership of the European Commission in cooperation with the authorities of various territorial levels, as well as the European Center for Journalism in Maastricht, thematic educational events are regularly held to prepare journalists to cover integration 
topics, a breeding ground for research has formed for more than 2 decades. But the issues concerning the role of mass media in coverage of the processes of the regional integration are of interest not only to the EU media researchers.

The representatives of the research community of the least integrated region of the world - Africa - are also actively engaged in assessing the impact of mass media on the efficiency of the integration processes. The works on media support to the regional integration of the States of the East African Community, as well as problems of cooperation between the countries of the African Union and its blocs are of particular interest (Didiugwu, 2014; Mang'era, 2014). 'The only true path for Africa is a single political, cultural and economic voice. And this becomes clear due to the success of the European Union' (Didiugwu, 2014). 'The regional integration in Africa is increasingly being identified as an essential component of economic and political development; mass media, on which all efforts are based, should be perceived as the most important agent of this mission. Their role cannot be overestimated' (Didiugwu, 2014). But if the key issues for these researchers are to identify and find solutions to such regional issues, preventing the forming of the regional agenda, as problems of general underfunding of the sector, low level of technical equipment of enterprises and wages and total control of media companies by national governments (Churchill, 1991; Didiugwu, 2014; Mang'era, 2014; Tettey, 2001), then for the European scientific community, the priority is currently the analysis of news media content in order to identify the relationship between the national and European contexts.

This trend is related to the fact that at the early stages two main ways of development of the European public sphere were identified (Gerhards, 1993):

- creation of an international European-wide public sphere based on a unified system of mass media;

- Europeanization of national public spheres through thematization (coverage of the European topics in national mass media and assessment of them from a supranational point of view, rather than through a 'national prism').

However, with the growing practical importance of this issue, these criteria were partially reformulated, specified and supplemented by such requirements for transnationalization as synchronization and interaction. In the papers of modern researchers, the view prevails, that the emergence of a Europeanwide public on the basis of a unified media system is much less likely than the Europeanization of the national communities (Eilders, 2003; Pfetsch, 2008). Therefore, the current empirical research focuses on the coverage of the 
European Union in national media (Bruter, 2005; Kevin, 2015; Lohner, 2011; Pfetsch, 2008). Taking into account the absence of a Eurasian-wide media infrastructure, as well as barriers to the creation of a trans-border public sphere, due to the peculiarities of the development of the national media systems of the FSU states (Temirbulatov, 2013; Vartanova, 2014; Venidiktov, 2016), this approach is reasonable to apply when analyzing the media support to the integration processes in the Eurasian Economic Union.

But if, in the theoretical formulation of the question, it is acceptable to rely on certain theses proposed within the studies on the information policy of the CIS countries (Hradziushka et al., 2020; Kalyuga, 2016; Popov, 2015; Strugovets, 2011) and some aspects of the formation and the coordination of its information space (Poddubskaya, 2018; Temirbulatov, 2013; Vartanova, 2019) and theoretical studies that are directly relevant to the subject of the EAEU media space (Galitsina, 2017; Venidiktov, 2016; Vikhrova, 2020), the empirical research on the proposed topic is practically absent today.

Do the mainstream media of the Eurasian Economic Union countries contribute to the spread of integration sentiments and ideas among the citizens? Do they ensure that the information space is filled thematically and quantitatively enough to ensure that the Eurasian agenda is anchored in the national information spaces, and that integration within the EAEU is supported by the public? In the context of attempts to destabilize the geopolitical situation in the region and the growing information confrontation, these research issues both do not lose their relevance, but also become particularly important. The answers to them can help to build a more efficient information policy within the region that can directly influence the further development of the post-Soviet space.

The purpose of this study is to identify thematic dominants in the coverage of the Eurasian integration by mainstream social and political media in Russia, Belarus, Kazakhstan, Armenia, and Kyrgyzstan.

In this regard, the following tasks were formulated:

- by means of frequent and thematic analysis of the news content of the leading TV channels, as well as print and online media of the member states, to identify which components of the image of the integration association that affect the perception of the EAEU by the population of the countries, and to what extent, are offered to the audience;

- to create a classifier that provides a comprehensive view of the thematic structure of the Eurasian agenda formed by the media of the participating states; 
- based on the results obtained, it is necessary to assess the present role of mass media in consolidating the Eurasian agenda in the information space of the participating states.

As part of the study, the materials of news programs, sections/blocks for the period from October 1 to December 31, 2019, of the mainstream social and political mass media of the EAEU countries were analyzed:

- 5 leading TV channels of Russia, Belarus, Kazakhstan, Armenia, and Kyrgyzstan.

- 5 leading print media in Russia, Belarus, Kazakhstan, Armenia, and Kyrgyzstan.

- 5 leading online media in Russia, Belarus, Kazakhstan, Armenia, and Kyrgyzstan.

The study period was Q4 2019, as it is not only sufficient, but also representative from the point of view of the formation of the thematic agenda. From October 1 to December 31, there were no events that had a significant impact on it or distorted it for a long time, as it happened, for example, in the second half of Q1 and Q2 2020, when COVID-19 became the main newsbreak for the vast majority of the social and political media.

1. The frequency of references to the EAEU in the news programmes, sections and blocks of the analyzed media was assessed. Each topic within one day was included in the calculation once.

Explanation:

a. If the identical item about the meeting of the EAEU leaders on December 20 was repeated in 3 news releases of Belarus 1 TV channel repeated, the number of mentions $=1$. But if the story was repeated in the weekly programme, it was included in the calculation for Sunday again.

b. If the topic of the EAEU summit in the afternoon cast on December 20 was covered as general, in order to inform about the meeting, and the plot of the evening cast was specified (dedicated to one of the topics discussed during the EAEU meeting), the total number of mentions $=2$.

1. The main topics in connection with which the EAEU is mentioned in the analyzed media, as well as the share of the materials related to each of them, were identified and classified. Based on the results obtained, a corresponding thematic classifier was created for each type of media.

2. On the basis of the final data, a single classifier was developed that illustrates the thematic content of the Eurasian agenda in the national information space at present and the volume of the relevant materials. 


\section{The EAEU in the news content of TV channels of the Union countries}

Despite the increasing role of online media and social media in the formation of the national agendas of the EAEU countries, television remains one of the leading types of media in the post-Soviet states. The news content offered to the audience by the leading national news channels has a significant impact on its perception of the surrounding reality. Especially when it comes to information related to the political and economic situation in the country and the world.

About $96 \%$ of the Russian population has at least one TV at home, and 50\% to $65 \%$ of citizens watch it every day ${ }^{4}$. At the same time, it should be noted that of five countries of the Union, the most rapidly declining performance of television audience and the outflow of advertising budgets to the Internet are observed in Russia. The average weekly television audience in Kyrgyzstan is $92.6 \%$ of the population, and over $60 \%$ of citizens still use it as the main information source ${ }^{5}$. Despite the fact that in Kazakhstan the share of the audience that prefers to receive news information from Internet resources has increased from $28 \%$ to $59 \%$ over the past five years, television is still the most preferred type of media (Alinbekova, 2019).

Currently, the number of references to the Eurasian Economic Union in the news programmes of the leading TV channels of the Union is insignificant. The total number of news items for the IV quarter of 2019 is presented in Table . The average figure for the leading Russian TV channels is 2.6 news per month, for Kazakhstan - 3.6, for Kyrgyzstan - 0.9. The indicators of the mainstream TV channels of Belarus ('Belarus 1') and Armenia ('N1') are slightly different: 78 and 66 items for the Q4, respectively. But against the background of the 'zero' indicators of 'Belarus 2' and 'Belarus 3', as well as the low indicators of other Armenian TV channels confirming the overall picture, these parameters do not have a significant impact on the overall statistical picture. The average figure for Belarus is 10.5, for Armenia - 8.3 news items per month.

In the analysis of the monthly ratio of the number of news TV stories of the EAEU TV channels, it becomes obvious that the months of events with the participation of the heads of the member countries show the highest quantitative indicators. For example, the meetings of the Supreme Eurasian Economic Council were held on October 1 in Yerevan and December 20 in St.

${ }^{4}$ Television in Russia in 2019. Rospechat report.

${ }^{5}$ Media preferences of the population of Kyrgyzstan. Available from: https:// soros.kg/wp-content/uploads/2017/12/Otchet-Mediapredpochteniya-naseleniyaKR-8-volna.pdf 
Petersburg. As a result, in October on the Russian TV channels there were 14 of 39 videos dedicated to the EAEU in the context of this event, and in December there were 17 of 39 videos on the Russian TV channels. In their turn, in October the journalists of Armenian TV channels offered the audience 57 thematic news stories out of 124, which fell at Q4, and the number of December news segments also significantly exceeded November poor for such events. Similar figures are reflected in the statistics of Kazakhstan.

However, despite the opportunities that TV audience coverage still provides and the declared interest of the authorities in the promotion of the Eurasian agenda at state levels, the average number of newsbreaks for Q4 2019 for any of the considered blocks of the national TV channels does not exceed ten.

Table 1

Frequency of references to the EAEU in the news programmes of the TV channels of the Union countries, Q4 2019

\begin{tabular}{|l|c|l|c|c|c|c|c|c|c|}
\hline \multicolumn{2}{|c|}{ Russia } & \multicolumn{2}{c|}{ Belarus } & \multicolumn{2}{c|}{ Kazakhstan } & \multicolumn{2}{c|}{ Armenia } & \multicolumn{2}{c|}{ Kyrgyzstan } \\
\hline $\begin{array}{l}\text { TV } \\
\text { channel }\end{array}$ & $\begin{array}{l}\text { Num- } \\
\text { ber of } \\
\text { items }\end{array}$ & $\begin{array}{l}\text { TV } \\
\text { channel }\end{array}$ & $\begin{array}{l}\text { Num- } \\
\text { ber of } \\
\text { items }\end{array}$ & $\begin{array}{l}\text { TV } \\
\text { channel }\end{array}$ & $\begin{array}{l}\text { Num- } \\
\text { ber of } \\
\text { items }\end{array}$ & $\begin{array}{c}\text { TV } \\
\text { channel }\end{array}$ & $\begin{array}{c}\text { Num- } \\
\text { ber of } \\
\text { items }\end{array}$ & $\begin{array}{c}\text { TV } \\
\text { channel }\end{array}$ & $\begin{array}{c}\text { Num- } \\
\text { ber of } \\
\text { items }\end{array}$ \\
\hline 1 TV & 9 & $\begin{array}{l}\text { Belarus } \\
1\end{array}$ & 78 & Khabar & 8 & N1 & 66 & KTRK & 4 \\
\hline NTV & 9 & $\begin{array}{l}\text { Belarus } \\
2\end{array}$ & 0 & $\begin{array}{l}\text { Khabar } \\
24\end{array}$ & 26 & Shant & 26 & World & 1 \\
\hline Russia 1 & 9 & ONT & 45 & $\begin{array}{l}\text { Atame- } \\
\text { ken } \\
\text { Business }\end{array}$ & 11 & Armenia & 15 & NTS & 3 \\
\hline $\begin{array}{l}\text { TV } \\
\text { Center }\end{array}$ & 5 & STV & 34 & KTK & 3 & Kentron & 12 & & \\
\hline $\begin{array}{l}6 \\
\text { Channel }\end{array}$ & 7 & World & 27 & Eurasia & 6 & $\begin{array}{l}\text { Fifth } \\
\text { Channel }\end{array}$ & 5 & & \\
\hline
\end{tabular}

The thematic structure of the 'Eurasian news content' of national TV channels is also limited. 'Meetings of the leaders of the EAEU Member States', as well as 'Prospects for the development of relations between the countries participating in the integration association and strengthening ties with external partners' are the thematic dominants in the news blocks of TV channels of Armenia, Kazakhstan, Russia, and Belarus (Table 2). 
Table 2

Thematic structure of the news content of the TV channels dedicated to the EAEU, for October 01, 2019, to December 31, 2019.

\begin{tabular}{|c|c|c|c|c|c|}
\hline \multirow[t]{2}{*}{ Subject matter } & \multicolumn{5}{|c|}{$\begin{array}{l}\text { Per cent that the subject matter has } \\
\text { in the total volume of news content } \\
\text { of TV channels dedicated to the EAEU }\end{array}$} \\
\hline & Russia & Belarus & Kazakhstan & Armenia & Kyrgyzstan \\
\hline $\begin{array}{l}\text { Meeting of the leaders } \\
\text { of the EAEU States }\end{array}$ & 49.2 & 48.5 & 13.4 & 40.6 & 25.0 \\
\hline $\begin{array}{l}\text { Prospects for the } \\
\text { development of relations } \\
\text { between the countries } \\
\text { of the integration } \\
\text { association, as well } \\
\text { as strengthening ties with } \\
\text { external partners }\end{array}$ & 17.8 & 14.2 & 51.0 & 23.1 & 12.5 \\
\hline Legislative regulation & 17.4 & 7.8 & 23.5 & 20.8 & 50.0 \\
\hline $\begin{array}{l}\text { Certain statements } \\
\text { and pronouncements } \\
\text { of the leaders of the EAEU } \\
\text { States, comments and } \\
\text { assessments of experts }\end{array}$ & 15.6 & 29.5 & 12.1 & 14.1 & 0 \\
\hline $\begin{array}{l}\text { Personnel appointments } \\
\text { in the institutions of the } \\
\text { EAEU }\end{array}$ & 0 & 0 & 0 & 1.4 & 0 \\
\hline $\begin{array}{l}\text { Mutual trade between } \\
\text { the EAEU States }\end{array}$ & 0 & 0 & 0 & 0 & 12.5 \\
\hline
\end{tabular}

In the Republic of Kyrgyzstan, coverage of the issues related to legislative regulation comes to the fore. It must be emphasized that despite the fact that all members of the research group worked on the territory of their states independently from each other, the thematic range for 4 of the 5 analyzed national TV channels turned to be one, that on the one hand, facilitated the creation of the classifier and grouping of newsbreaks unified for all countries, and with another - is an illustration of the critical limitations of the contexts in which the topics the young regional association is covered.

Only Kyrgyzstan has highlighted the thematic block of materials "Mutual trade between the EAEU States" different from other countries since the number of media materials offering the audience news about statistical data and other indicators describing the dynamics of mutual trade between the member countries is significant in this country. 
But if we consider this block, which Kazakhstan has allocated to a separate group based on the inclusion of only statistical data on trade turnover presented by the media as part of the segments 'Comments and assessments of experts' and 'Prospects for the development of relations between the participating countries', the picture becomes even more gloomy.

When comparing the topics of media content about the EAEU on TV channels, we can note the predominance of the block 'Meetings of the leaders of the EAEU States' and 'Individual statements and statements of the leaders of the EAEU countries, comments and assessments of experts' on TV in Belarus (up to $50.2 \%$ of the total number of materials) and Armenia (up to $50 \%$ of the total number of materials). The TV channels of Russia and Kyrgyzstan have almost the same indicators for all the designated topics. The situation on TV in Kazakhstan is interesting: on 4 out of 5 TV channels considered, the coverage of the topic 'Prospects for the development of relations between the countries participating in the integration association, as well as strengthening ties with external partners' reaches $66.68 \%$, which is almost twice the average indicators of other countries. This is due to the position of the state: the inviolability of political sovereignty and the promotion of their own national interests within the framework of the EAEU.

\section{The EAEU in the news content of print media}

The role of print media in the formation of national agendas in the EAEU differs from country to country. While the Russian print media are rapidly losing their audience year after year, entering 2020 with indicator of $71 \%$ and yielding to radio $(86 \%)^{6}$, newspapers in Belarus are trying to adapt to digital formats and do not always efficiently cope with competition with social media, which quickly adopted the role of the main sources of information for the population amid the political crisis. At the same time, Kyrgyzstan and Kazakhstan are in the 'transitional period' distinctive for Belarus in 2017, when the consumption of print and online media content is almost equal, although significantly inferior to the popularity of television.

The number of news items of print media of the countries that cover the events related to the Eurasian Economic Union, as well as mentions of the regional association, exceeds the number of TV channels offered to viewers, but is also insignificant and insufficient to form a media portrait of the EAEU and consolidate it in the minds of the public (Table 3). The exception is 'Rossiyskaya

${ }^{6}$ Press 2020. Available from: https://mediascope.net/upload/iblock/4a3/Mediascope_Publishing_Expo_2020.pdf 
Gazeta', which is the official print media of the Government of the Russian Federation. One should note that the publication, which has the status of the official publisher of federal documents, also offers infotainment materials. They are unique in terms of coverage of the Eurasian topics, which are absent in other publications of the Union countries. Their number is insignificant (2 articles out of 160), but amid the absence of similar materials in other print and online media of the states (the only exception is BelTA), this fact deserves special attention of the researchers.

The average number of thematic items for Russian print media is 19.8; for Belarusian - 8.3; print media of Kazakhstan - 13.9; Armenia - 5.5; Kyrgyzstan -0.7.

Table 3

Frequency of references to the EAEU in the news content of the print media, Q4 2019

\begin{tabular}{|c|c|c|c|c|c|c|c|c|c|}
\hline \multicolumn{2}{|c|}{ Russia } & \multicolumn{2}{|c|}{ Belarus } & \multicolumn{2}{|c|}{ Kazakhstan } & \multicolumn{2}{|c|}{ Armenia } & \multicolumn{2}{|c|}{ Kyrgyzstan } \\
\hline $\begin{array}{l}\text { Print } \\
\text { media }\end{array}$ & $\begin{array}{l}\text { Num- } \\
\text { ber of } \\
\text { items }\end{array}$ & $\begin{array}{l}\text { Print } \\
\text { media }\end{array}$ & $\begin{array}{l}\text { Num- } \\
\text { ber of } \\
\text { items }\end{array}$ & $\begin{array}{l}\text { Print } \\
\text { media }\end{array}$ & $\begin{array}{l}\text { Num- } \\
\text { ber of } \\
\text { items }\end{array}$ & $\begin{array}{c}\text { Print } \\
\text { media }\end{array}$ & $\begin{array}{l}\text { Num- } \\
\text { ber of } \\
\text { items }\end{array}$ & $\begin{array}{c}\text { Print } \\
\text { media }\end{array}$ & $\begin{array}{l}\text { Num- } \\
\text { ber of } \\
\text { items }\end{array}$ \\
\hline $\begin{array}{l}\text { Vedo- } \\
\text { mosti }\end{array}$ & 36 & \begin{tabular}{|l} 
SB. \\
Belarus \\
Today
\end{tabular} & 52 & Vremya & 64 & $\begin{array}{l}\text { Hayka- } \\
\text { kan } \\
\text { Zha- } \\
\text { manak }\end{array}$ & 40 & $\begin{array}{l}\text { Komso- } \\
\text { mols- } \\
\text { kaya } \\
\text { Pravda } \\
\text { in the } \\
\text { KG } \\
\end{array}$ & 2 \\
\hline $\begin{array}{l}\text { Kommer- } \\
\text { sant }\end{array}$ & 42 & Respublika & 22 & $\begin{array}{l}\text { Egemen } \\
\text { Қаzақstan }\end{array}$ & 11 & $\begin{array}{l}\text { The } \\
\text { Zho-gh- } \\
\text { ovurd }\end{array}$ & 16 & $\begin{array}{l}\text { Kyrqyz } \\
\text { Tuusu }\end{array}$ & 0 \\
\hline Izvestiya & 59 & $\begin{array}{l}\text { Narodnaya } \\
\text { Gazeta }\end{array}$ & 8 & Kursiv & 84 & Aravot & 22 & \begin{tabular}{|l} 
Aziya \\
News
\end{tabular} & 0 \\
\hline $\begin{array}{l}\text { Rossiy- } \\
\text { skaya } \\
\text { Gazeta }\end{array}$ & 160 & $\begin{array}{l}\text { Selskaya } \\
\text { Gazeta }\end{array}$ & 6 & Liter & 26 & Past & 4 & $\begin{array}{l}\text { Zhany } \\
\text { Ordo }\end{array}$ & 0 \\
\hline \begin{tabular}{|l|} 
Komso- \\
molskaya \\
Pravda
\end{tabular} & 0 & Zvyazda & 37 & Express-K & 23 & \begin{tabular}{|l} 
Zha- \\
manak
\end{tabular} & 0 & $\begin{array}{c}\text { Super } \\
\text { Info }\end{array}$ & 0 \\
\hline
\end{tabular}

The number of contexts in which the subject of the EAEU is covered, as in the case of TV channels, is limited, as is the case with TV channels. The print media of the Russian Federation primarily focuses on the issues related to legislative regulation. Journalists of Kyrgyzstan, Belarus, and Armenia build the Eurasian agenda around the meetings of the leaders of the Union member states, and the 
print media of Kazakhstan are based on newsworthy related to the prospects of the development of relations between the countries participating in the integration association (Table 4).

Table 4

Thematic structure of the news content of the print media, from October 01, 2019, to December 31, 2019.

\begin{tabular}{|c|c|c|c|c|c|}
\hline \multirow[t]{2}{*}{ Subject matter } & \multicolumn{5}{|c|}{$\begin{array}{l}\text { Per cent, which the topic occupies } \\
\text { in the total volume of news content dedicated } \\
\text { to the EAEU in print media }\end{array}$} \\
\hline & Russia & Belarus & Kazakhstan & Armenia & Kyrgyzstan \\
\hline $\begin{array}{l}\text { Meeting of the leaders } \\
\text { of the EAEU States }\end{array}$ & 5.8 & 42.8 & 8.6 & 36.9 & 50 \\
\hline $\begin{array}{l}\text { Prospects for the } \\
\text { development of relations } \\
\text { between the countries } \\
\text { of the integration } \\
\text { association, as well as } \\
\text { strengthening ties with } \\
\text { external partners }\end{array}$ & 27.5 & 8.5 & 41.9 & 18.9 & 50 \\
\hline Legislative regulation & 48.4 & 14.4 & 44.5 & 8.4 & 0 \\
\hline $\begin{array}{l}\text { Certain statements and } \\
\text { pronouncements of the } \\
\text { leaders of the EAEU } \\
\text { States, comments and } \\
\text { assessments of experts }\end{array}$ & 18.3 & 34.3 & 5.0 & 32.3 & 0 \\
\hline $\begin{array}{l}\text { Personnel appointments } \\
\text { in the institutions of the } \\
\text { EAEU }\end{array}$ & 0 & 0 & 0 & 3.5 & 0 \\
\hline $\begin{array}{l}\text { Mutual trade between } \\
\text { the EAEU States }\end{array}$ & 0 & 0 & 0 & 0 & 0 \\
\hline
\end{tabular}

\section{The EAEU in the news content of online publications}

Only the registered online media of the member states are reviewed within this study, but it should be noted that social media greatly affect the information space of the states and the Eurasian agenda. In particular, Telegram channels are popular with the audience of Russia, Kazakhstan, and Belarus. 
In addition to the data presented in Table 5 , it should be noted that the average monthly index of the frequency of references to the EAEU by the leading online publications of the countries varies from 1.6 to 33. (The average indicator for the leading Russian online media is 15 items per month, for Belarusian 30.3; for Kazakhstani - 6.5; Armenian - 33; Kyrgyz - 1.6.)

Table 5

Frequency of references to the EAEU in the news content of the online media, Q4 2019

\begin{tabular}{|c|c|c|c|c|c|c|c|c|c|}
\hline \multicolumn{2}{|c|}{ Russia } & \multicolumn{2}{|c|}{ Belarus } & \multicolumn{2}{|c|}{ Kazakhstan } & \multicolumn{2}{|c|}{ Armenia } & \multicolumn{2}{|c|}{ Kyrgyzstan } \\
\hline $\begin{array}{l}\text { Online } \\
\text { media }\end{array}$ & $\begin{array}{l}\text { Num- } \\
\text { ber of } \\
\text { items }\end{array}$ & \begin{tabular}{|l|} 
Online \\
media
\end{tabular} & $\begin{array}{l}\text { Num- } \\
\text { ber of } \\
\text { items }\end{array}$ & $\begin{array}{l}\text { Online } \\
\text { media }\end{array}$ & $\begin{array}{l}\text { Num- } \\
\text { ber of } \\
\text { items }\end{array}$ & $\begin{array}{l}\text { Online } \\
\text { media }\end{array}$ & $\begin{array}{l}\text { Num- } \\
\text { ber of } \\
\text { items }\end{array}$ & $\begin{array}{l}\text { Online } \\
\text { media }\end{array}$ & $\begin{array}{l}\text { Num- } \\
\text { ber of } \\
\text { items }\end{array}$ \\
\hline $360 \mathrm{tv}$ & 23 & BelTA & 296 & $\begin{array}{l}\text { Inform- } \\
\text { bureau }\end{array}$ & 11 & $\begin{array}{c}\text { Newsar- } \\
\text { menia.am }\end{array}$ & 68 & $\begin{array}{c}\text { Kaktus. } \\
\text { media }\end{array}$ & 3 \\
\hline RBK & 74 & \begin{tabular}{|l|} 
Tut.by \\
\end{tabular} & 63 & $\begin{array}{c}\text { Tengri- } \\
\text { news }\end{array}$ & 38 & News.am & 110 & $24 . \mathrm{kg}$ & 14 \\
\hline Gazeta.ru & 18 & $\begin{array}{c}\text { Onliner. } \\
\text { by }\end{array}$ & 17 & $\begin{array}{c}\text { Today. } \\
\text { kz }\end{array}$ & 11 & $\begin{array}{c}\text { Shamshy- } \\
\text { an.com }\end{array}$ & 19 & $\begin{array}{c}\text { Kabar. } \\
\text { kg }\end{array}$ & 1 \\
\hline Lenta.ru & 57 & $\begin{array}{c}\text { Naviny. } \\
\text { by. Be- } \\
\text { larusian } \\
\text { news }\end{array}$ & 58 & $\begin{array}{c}\text { Matrix. } \\
\text { kz }\end{array}$ & 17 & Mamul.am & 53 & $\begin{array}{c}\text { Aki- } \\
\text { press. } \\
\text { org }\end{array}$ & 1 \\
\hline RT & 53 & \begin{tabular}{|c|} 
Nasha \\
Niva
\end{tabular} & 21 & $\begin{array}{c}\text { Zakon. } \\
\text { kz }\end{array}$ & 21 & $\begin{array}{l}\text { Sputnik } \\
\text { Armenia }\end{array}$ & 245 & & \\
\hline
\end{tabular}

It should be noted that along with the leading online media in Armenia, Sputnik news agency's website was included in the sample, as according to media researchers, 'it largely shapes the opinion of the Armenian mass audience about the EAEU', and at that this involves both the population preferring the media in Armenian, as well as in Russian.

Despite such a significant gap, even the indicators of the Republic of Armenia and the Republic of Belarus cannot be called sufficient to fill the online news media with thematic content. The thematic structure duplicates the situation with the news content of the national TV channels and print media: the thematic spectrum is limited to the above-mentioned contexts (Table 6). 
Table 6

Thematic structure of the news content of the online media, from October 01, 2019, to December 31, 2019

\begin{tabular}{|c|c|c|c|c|c|}
\hline \multirow[t]{2}{*}{ Subject matter } & \multicolumn{5}{|c|}{$\begin{array}{c}\text { Per cent, which the topic occupies } \\
\text { in the total volume of news content dedicated } \\
\text { to the EAEU in online media }\end{array}$} \\
\hline & Russia & Belarus & Kazakhstan & Armenia & Kyrgyzstan \\
\hline $\begin{array}{l}\text { Meeting of the leaders } \\
\text { of the EAEU States }\end{array}$ & 5.4 & 37.5 & 8.4 & 28.4 & 0.0 \\
\hline $\begin{array}{l}\text { Prospects for the } \\
\text { development of relations } \\
\text { between the countries of } \\
\text { the integration association, } \\
\text { as well as strengthening ties } \\
\text { with external partners }\end{array}$ & 34.1 & 39.2 & 38.9 & 24.6 & 16.6 \\
\hline Legislative regulation & 44.9 & 6.9 & 43.0 & 9.9 & 5.6 \\
\hline $\begin{array}{l}\text { Certain statements and } \\
\text { pronouncements of the } \\
\text { leaders of the EAEU States, } \\
\text { comments and assessments } \\
\text { of experts }\end{array}$ & 13.5 & 14.5 & 9.7 & 33.4 & 0 \\
\hline $\begin{array}{l}\text { Personnel appointments in } \\
\text { the institutions of the EAEU }\end{array}$ & 2.1 & 1.9 & 0 & 3.7 & 0 \\
\hline $\begin{array}{l}\text { Mutual trade between the } \\
\text { EAEU States }\end{array}$ & 0 & 0 & 0 & 0 & 77.8 \\
\hline
\end{tabular}

Table 7 presents combined thematic structure of the Eurasian agenda in national information spaces. Content analysis of TV channels, print and online media, viewed through the prism of national strategies and expectations regarding the role of the Eurasian Economic Union, allows us to better understand the positions of the participating states in relation to regional integration. 
Table 7

Thematic structure of the Eurasian agenda in the national information space for the period October 1, 2019, to December 31, 2019

\begin{tabular}{|c|c|c|c|c|c|c|c|c|c|c|}
\hline \multirow[b]{2}{*}{ Subject matter } & \multicolumn{5}{|c|}{$\begin{array}{l}\text { Per cent of media in which } \\
\text { it can be found }\end{array}$} & \multicolumn{5}{|c|}{$\begin{array}{c}\text { Per cent that the subject } \\
\text { matter takes } \\
\text { in the total number } \\
\text { of media publications } \\
\text { about the EAEU }\end{array}$} \\
\hline & 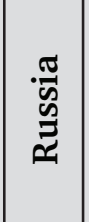 & 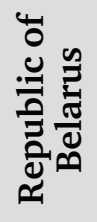 & 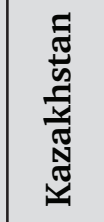 & 麁 & 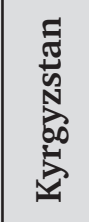 & 焉 & 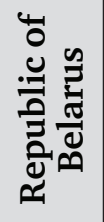 & 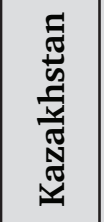 & 营 & 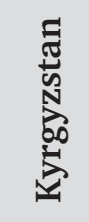 \\
\hline $\begin{array}{l}\text { Meeting of the } \\
\text { leaders of the EAEU } \\
\text { States }\end{array}$ & 78.6 & 100 & 100 & 100 & 37.5 & 21.1 & 42.9 & 10.14 & 29.1 & 15.0 \\
\hline $\begin{array}{l}\text { Prospects for the } \\
\text { development of } \\
\text { relations between } \\
\text { the countries of } \\
\text { the integration } \\
\text { association, as well } \\
\text { as strengthening } \\
\text { ties with external } \\
\text { partners }\end{array}$ & 78.6 & 100 & 100 & 100 & 50 & 26.4 & 20.6 & 43.92 & 24.7 & 17.8 \\
\hline $\begin{array}{l}\text { Legislative } \\
\text { regulation }\end{array}$ & 85.7 & 85.7 & 86.67 & 92.9 & 50 & 36.1 & 9.7 & 37.02 & 12 & 27.5 \\
\hline $\begin{array}{l}\text { Certain } \\
\text { statements and } \\
\text { pronouncements } \\
\text { of the leaders of } \\
\text { the EAEU States, } \\
\text { comments and } \\
\text { assessments of } \\
\text { experts }\end{array}$ & 64.2 & 100 & 93.33 & 92.9 & - & 15.6 & 25.5 & 8.92 & 31 & - \\
\hline $\begin{array}{l}\text { Personnel } \\
\text { appointments in the } \\
\text { institutions of the } \\
\text { EAEU }\end{array}$ & 7.1 & 60 & - & 64.3 & - & 0.8 & 1.3 & - & 3.2 & - \\
\hline $\begin{array}{l}\text { Mutual trade } \\
\text { between the EAEU } \\
\text { States }\end{array}$ & - & - & - & - & 62.5 & - & - & - & - & 39.7 \\
\hline
\end{tabular}


When TV and online media, using their inherent advantages (image and speed of perception of information), demonstrate, first of all, the positive aspects of the integration processes of the Eurasian space, oppositely the situation in the print and online media of some post-Soviet republics is not so bright. It is not a matter of a relatively small number of published materials, but rather of highlighting the problems of integration and their impact on the promotion of their own national interests within the framework of the EAEU. For example, the mass media of Kyrgyzstan emphasizes that the reasons for the country's participation in the Eurasian Union are solely to ensure conditions for the country's economic growth, access of Kazakh products to foreign markets (the EAEU or third countries, using the EAEU countries as intermediaries), and attracting investment. At the same time, some dissatisfaction was noted when comparing the market volumes of the Customs Union of Russia and Belarus and the inflow of goods from these countries to Kazakhstan. Kyrgyzstan also pays great attention to the prospects of mutual trade of the EAEU member states. Therefore, as part of the content analysis, we identified a separate set of materials 'Mutual trade between the EAEU countries', separated from the segments 'Comments and assessments of experts' and 'Prospects for the development of relations between the EAEU member states'.

It is noteworthy that the opinions of individual independent experts are mostly negative or focused on a careful comparison of the positive and negative aspects in the EAEU.

At the same time, the media actively cover legislative initiatives aimed at forming one of the main principles of the development of the internal market of the EAEU - the elimination of barriers to mutual and equal access of national producers to the internal markets of the member States of the integration association. This work should be carried out more actively by the journalists of the EAEU countries, explaining the benefits of integration for national economies.

As it was repeatedly emphasized in the speeches of the heads of the EAEU member States, political figures, and various experts during the study period, the EAEU is aimed exclusively at economic integration. There are clear limits to the development of the EAEU: the firmness of political sovereignty, consensus at all levels of integration, and a pragmatic approach. For example, in the print media of Kazakhstan, special attention was paid to the introduction of a single currency on the territory of the EAEU.

Based on this, we can state that at the moment there is no consensus in the expert community of the EAEU countries about the integration prospects of 
the association. But still, upon the discussion of some general issues, including political, social, and economic ones, we can talk about the prospects for the future.

The mass media should better cover the progress and solution of integration problems and the prospects for participation in the EAEU. This will help to achieve the interest of a large part of society in the development of the EAEU association.

\section{Discussion}

Despite a number of studies containing both a theoretical justification for the need for information support to integration processes in the Eurasian space (Vartanova, 2019; Vikhrova, 2020, etc.), as well as a practical evaluation of its impact on the success of other regional projects (Kandyla \& De Vreese, 2011; Triga \& Vadratsikas, 2016-2018, etc.), the results obtained from the content analysis demonstrate that at present the media's activities on the information support of the Eurasian integration can be assessed as unregulated, unstimulated (in the sense of unmotivated) from outside and inefficient. The frequency of mentions of the EAEU by the leading media of the member states is extremely low (the average monthly indicator for TV channels of the countries -5 news, for online media - 17 materials), and the number of contexts, which cover the topic of the young regional association, does not exceed five in the most states of the Union. Meetings of heads of state, prospects for the development of relations of the member countries and strengthening of ties with external partners, legislative regulation, as well as official statements of the leaders of the EAEU countries make up over $90 \%$ of the thematic agenda of the Union states.

In order to fill the national information spaces with content aimed at the promotion of the integration ideas among the population, it is reasonable to develop and implement certain elements of a unified information policy in the space of the Union. At the current stage, the EAEU is far from creating and supranational regulation of a unified information space, but even today the logic of the performance of the coordinated information policy can be built on the principle of joining of different participants around the specific projects, including those focused on the improvement of the efficiency of information support for the integration processes. The projects can extend to different territorial levels - regional, national or Eurasian, but coordinating such work at any of them requires a clear understanding of the logic of the performance and careful preliminary study of the media systems of each state. 
Despite the fact that today the countries are united by access to the Internet and information and communications technology (ICT), which greatly facilitates information exchange, media systems of the states have developed independently for a long time. Until 1991, the media and journalism of Armenia, Belarus, Kazakhstan, Kyrgyzstan, and Russia were built on the basis of similar funding principles, editorial standards and organization systems. But three decades after the collapse of the Soviet Union, the media systems of each state present completely different models, the coordination of which requires a detailed study of the features of their elements, and, therefore, additional research, which can follow this work.

The importance of the integration processes of the EAEU on the agenda in the mass media is much broader than it seems to many researchers. The four blocks of topics identified in the content analysis - 'Meetings of the leaders of the EAEU States', 'Prospects for the development of relations between the EAEU countries', 'Legislative regulation' and 'Individual statements of the leaders of the EAEU countries' - are basic, but each of them can be divided into sub-topics for more detailed research. For example, in the content analysis of the information space of Kyrgyzstan the topic 'Mutual trade between the EAEU countries Personnel assignments' is presented. In Kazakhstan, which sees only economic integration in the EAEU, media materials are studied through the prism of national plans and development programs of the republic (Khasenov \& Kenzhalina, 2019).

At the same time, there is a violation of the very idea of uniting countries in the Eurasian Union, in which the public, due to the insufficient coverage in the media, is poorly interested. Overcoming this limiting factor can be compensated by a well-thought-out state information policy in each of the countries, which should focus the media on the strategic needs and interests of society within the framework of the EAEU. At the same time, it should be remembered that the publication of materials about the EAEU is designed to provide not a dry statement of facts about the formation of an integration association, but freedom for creativity and continuous personal and professional development of journalistic personnel and the existing pool of experts on the EAEU issues.

Another obstacle to informing the public about the Eurasian Union is the traditional mass media industry. The speed of communication is dictated by new media. However, reading print media or watching TV in real time makes the consumption of information unavailable at the speed of communications. As a result, it is extremely difficult to form a reliable picture of the integration processes within the Eurasian Union. For comparison: the maximum frequency of mentions of the EAEU in news programs on Russian television in the study 
period was 9 (the maximum number), in print - 160, in online media - 74; in Kazakhstan - 28 materials on TV, 110 - in print and 38 - online. The largest volume of content about the EAEU is shown by the online media of Belarus 296 materials for the fourth quarter of 2019.

The example of Belarus proves that new media are becoming a truly effective tool for popularizing the Eurasian space. However, in this case, verification of the published information becomes a problem.

Having enormous opportunities to form the public's understanding of the events taking place in the EAEU member states, the mass media can not only inform about the existing or prospects for the development of national economies within the Eurasian Union, but also influence the public discourse on integration, strengthen or, conversely, reduce the cohesion of the EAEU population.

Currently, the media space of the Eurasian Union remains on the periphery of attention for both state institutions and the scientific and academic community.

The definition of the prospects for information support of the Eurasian integration is truly relevant, since the EAEU is only at the stage of forming a self-sufficient economic system.

The convergence made it possible to erase the previously existing traditional division of the mass media into print and electronic media, as well as information carriers. Not limited by state borders, the mass media becomes more vulnerable to the spread of unacceptable content, a planned flow of destabilizing information, including information wars. These concerns lead to the need to develop a certain image of the Eurasian Union not only globally, but also in the foreign information space.

In particular, the growing role of the Telegram messenger in the media space remains insufficiently studied in the Eurasian space. For instance, in Belarus, in 2020, the popularity of the Telegram messenger has significantly increased not only as a source of news information but also as a means of communication and self-organization in a political crisis. We believe that the most advantageous model is the one in which the media emphasize different ways of interacting with the audience.

The content analysis of the mass media and the identification of the main thematic focus of the media content of the EAEU member states allows us to state that the integration space not only lacks a uniform information field, following the example of the European Union, but also the journalists themselves are not interested in an effective response to the ongoing changes at the national level. 
In view of the information vacuum identified in the study and observed in practice within the Eurasian Economic Union, the issue of creating a content base to build the image of a young regional union on the global stage deserves special attention. In this regard, a scientific analysis of the EAEU image elements, spontaneously forming in foreign information spaces, is deemed necessary.

\section{Conclusion}

Shortly after the formation of the Union itself the media resources faced the problem of covering the activities of the Eurasian Economic Union. The importance of working in the information space to create a clear and positive image of the EAEU in the media is noted by both researchers, to which the authors of this work refer, and officials. However, despite numerous discussions, at the moment the coverage of the activities of the EAEU in the member states is characterized by unsystematic and relatively weak activity: the Eurasian integration has not been able to become one of the main topics of the social and political agenda in any of the member states of the Union. As spectacular examples it can be noted, that the EAEU's recognition among Russian citizens has increased by only $10 \%{ }^{7}$ over the years of existence, and Google Trends show that in all member states of the Union in terms of popularity the EAEU is consistently inferior to the Commonwealth of Independent States and is in popularity closer to the CSTO (and in Armenia it is inferior at all). The generated information vacuum is successfully filled by the opposition media, which promote the negative paradigm of consideration of the EAEU, seeing it as an instrument of new colonialism on the part of Russia.

The results of the study demonstrate that today the frequency of references to the EAEU by the leading media of the member states is low, and the number of contexts in which the topic of the young regional association is covered, is limited (Fig. 1, 2, 3, 4, 5).

${ }^{7}$ Eurasian integration: forms, goals, and consequences. // VCIOM (All-Russia Public Opinion Research Center) URL: https://wciom.ru/analytical-reviews/analiticheskii-obzor/evrazijskaya-integracziya-forma-czeli-i-posledstviya (access date: May 20, 2020) 
Figure 1

Thematic structure of the Russian media news content dedicated to the EAEU for the period from October 01, 2019, to December 31, 2019.

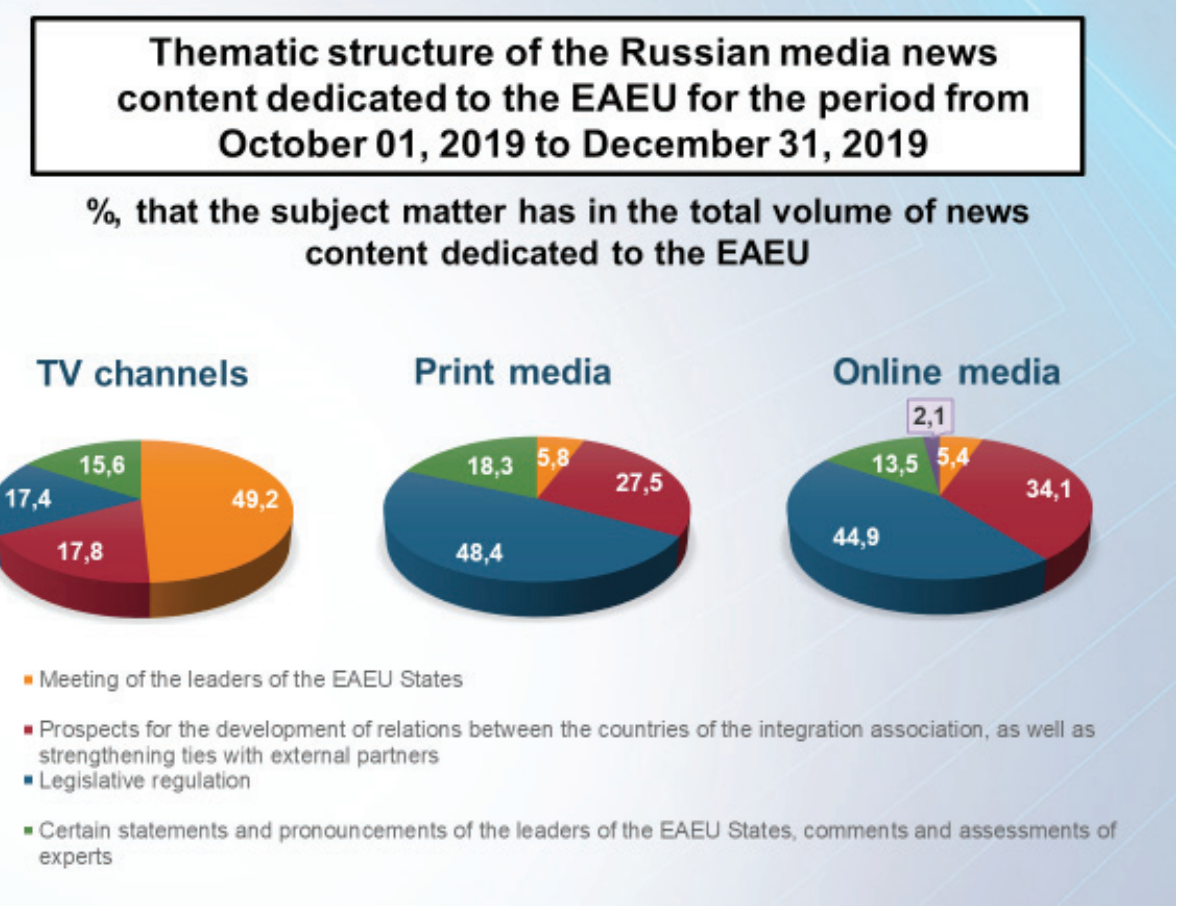

Source: The diagrams are prepared by the authors based on the data obtained during the study. 
Figure 2

Thematic structure of the Belarusian media news content dedicated to the EAEU for the period from October 01, 2019, to December 31, 2019.

\section{Thematic structure of the Belarusian media news content dedicated to the EAEU for the period from October 01, 2019 to December 31, 2019}

$\%$, that the subject matter has in the total volume of news content dedicated to the EAEU

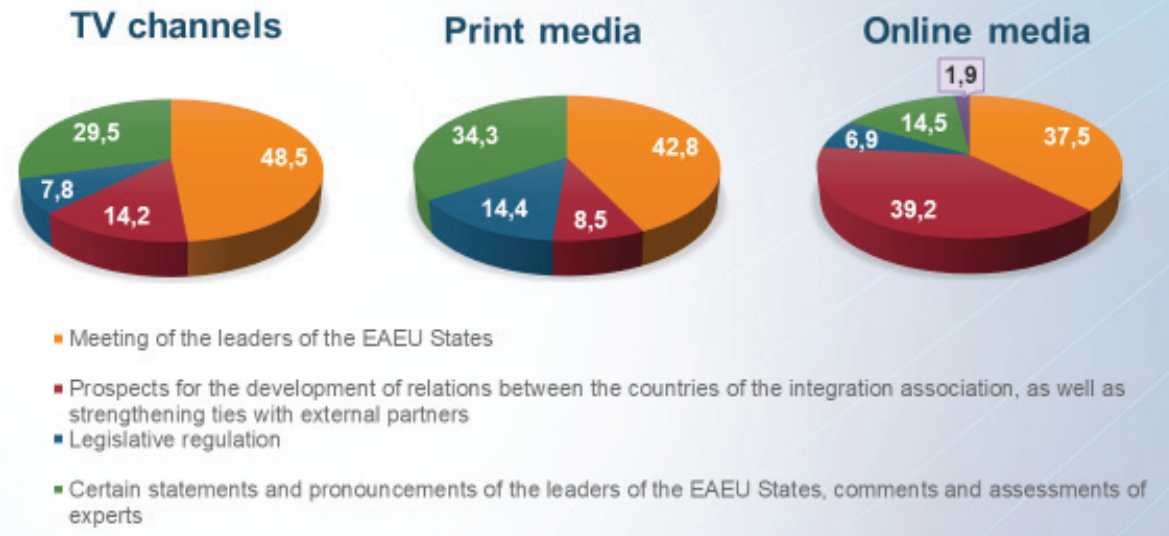

Source: The diagrams are prepared by the authors based on the data obtained during the study. 
Figure 3

Thematic structure of the media news content of Kazakhstan dedicated to the EAEU for the period from October 01, 2019, to December 31, 2019.

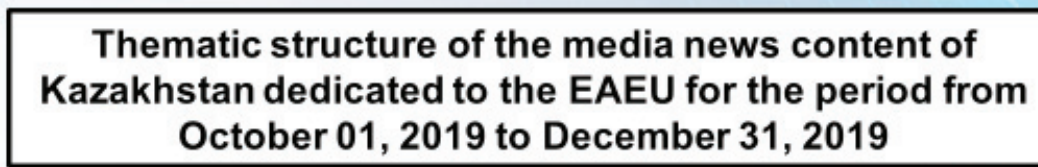

$\%$, that the subject matter has in the total volume of news content dedicated to the EAEU

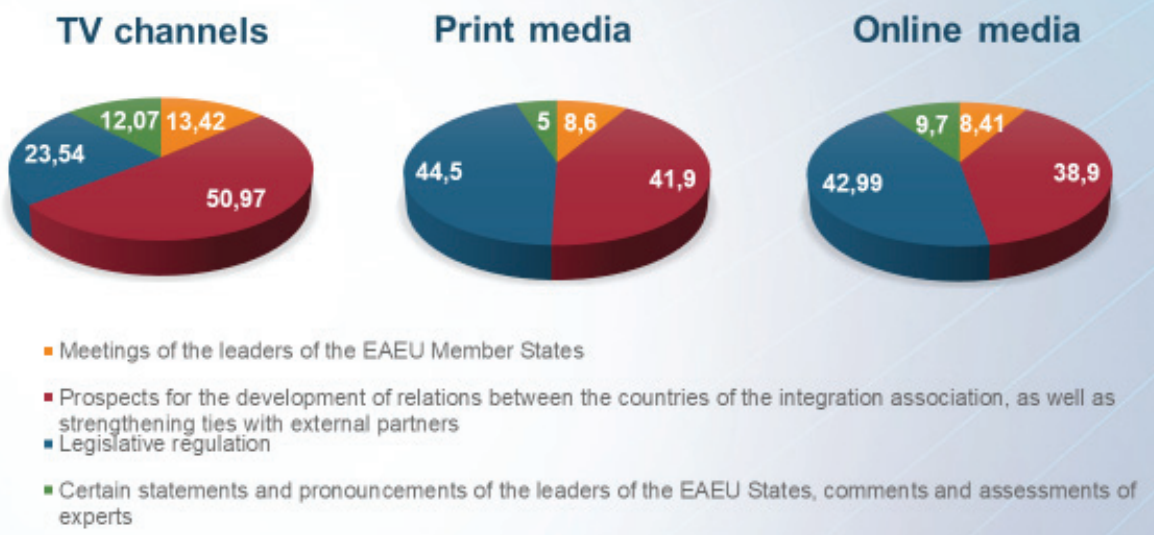

Source: The diagrams are prepared by the authors based on the data obtained during the study. 
Figure 4

Thematic structure of the Armenian media news content dedicated to the EAEU for the period from October 01, 2019, to December 31, 2019.

\section{Thematic structure of the Armenian media news content dedicated to the EAEU for the period from October 01, 2019 to December 31, 2019}

$\%$, that the subject matter has in the total volume of news content dedicated to the EAEU

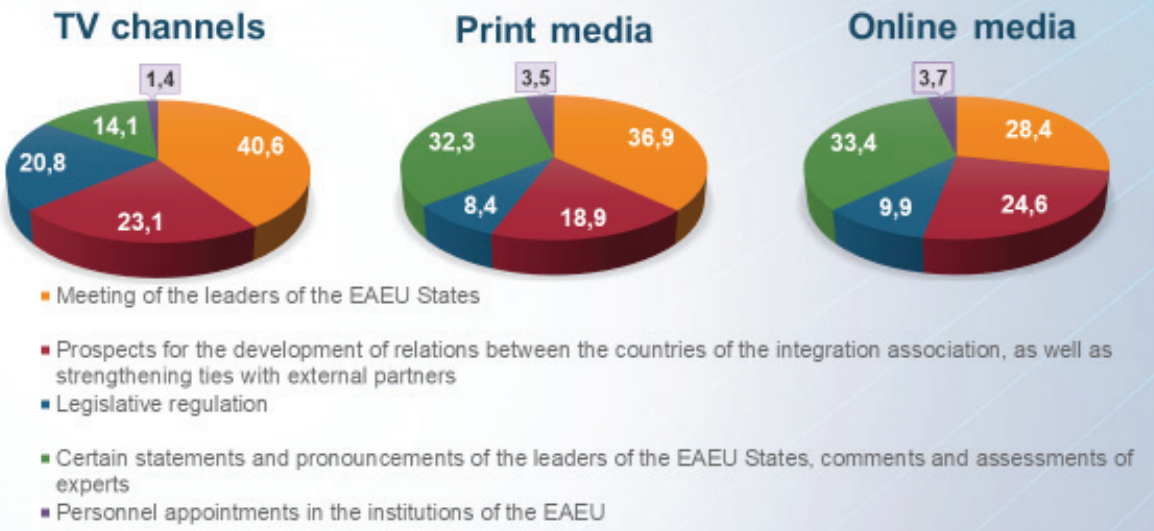

Source: The diagrams are prepared by the authors based on the data obtained during the study. 
Figure 5

Thematic structure of the media news content of Kyrgyzstan dedicated to the EAEU for the period from October 01, 2019, to December 31, 2019.

\section{Thematic structure of the media news content of Kyrgyzstan dedicated to the EAEU for the period from October 01, 2019 to December 31, 2019}

\section{$\%$, that the subject matter has in the total volume of news content dedicated to the EAEU}

TV channels

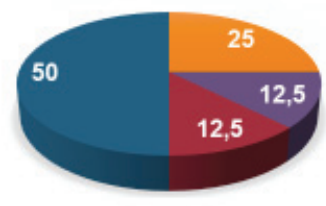

- Meetings of the leaders of the EAEU Member States

- Mutual trade between the EAEU States

- Prospects for the development of relations between the countries of the integration association, as well as strengthening ties with external partners

- Legislative regulation
Online media

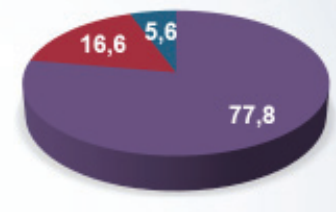

Print media

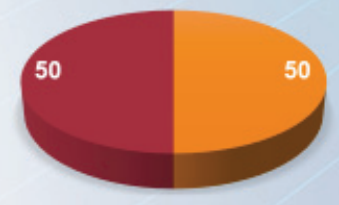

Source: The diagrams are prepared by the authors based on the data obtained during the study.

Since the Eurasian Economic Union is primarily an economic integration association, the results of its development and work should be of interest to citizens as the main consumers of goods and services. However, coverage of events related to the Union is currently formal. The main topics of the common information space of the EAEU countries as of Q4 2019 were:

- prospects for the development of relations between the countries of the integration association, as well as strengthening ties with external partners $-26.7 \%$,

- legislative regulation $-24.5 \%$,

- meetings of the leaders of the states of the integration association $23.7 \%$ of all news items of the mainstream social and political media of the participating countries,

- certain statements and pronouncements of the leaders of the EAEU States, comments and assessments of experts $-16.2 \%$. 
Another $8.9 \%$ of the news items of the mainstream social and political media of the participating countries were related to personnel changes and statistics of mutual trade between the countries, which are actively covered in Kyrgyzstan.

At the same time, the authors of the study note that the vast majority of the items in this small thematic spectrum are depersonalized information, but not personalized materials that clearly illustrate the benefits of the Eurasian integration for general public. All this leads to the formation of information apathy to the integration issues both in society and on the part of the journalists themselves.

The results of the study demonstrate that at present there is an urgent need to find efficient methods and incentives aimed at the promotion of the activities of media in order to solve the above-mentioned issues. Without the development of a set of measures aimed at improving the quality of information support, the EAEU risks to have an image of an interstate structure that has no practical significance, the results of operation of which do not affect the quality of public life. This, in its turn, can have a significant negative impact on the viability of the regional association, despite all efforts of the institutions of the Eurasian economic integration and many years of systematic work carried out by the governments of the participating states.

This situation is representational not only for the 'locomotive of Eurasian integration', but also for any other regional association represented on the global geopolitical map because in the 21st century, the success of the integration projects is determined not so much by the geo-economical potential, but by the public sphere formed by mass media of the participating states. This also confirms the concern of the Western researchers that in the periods relatively quiet for the European Union (Bijsmans \& Altides, 2007), the characteristics of the integration association policy do not correspond to the formats of media materials, since they mostly include 'technical details' that do not have a serious impact on the national policies and, therefore, are not of interest to the mass audience.

\section{References}

ALIMBEKOVA G. T. \& SHABDENOVA A. B. (2019) The media preferences of the population of Central Asian countries: Results of sociological research. Journal of the Belarusian State University. Sociology, 1, pp. 52-60.

BIJSMANS, P. \& ALTIDES, C. (2007). 'Bridging the gap' between EU politics and citizens? The European Commission, national media and EU affairs 
in the public sphere. Journal of European Integration, 29(3), pp. 323-340. DOI:10.1080/07036330701442315

BRUTER, M. (2005). Citizens of Europe? The emergence of a mass European identity. Palgrave Macmillan, UK. DOI: 10.1057/9780230501539.

CHURCHILL, E.-M. (1991). The mass media and regional integration in Africa. Africa Media Review, 5(1), pp. 17-35.

CLEMENT, A. A. (2015). Reporting on the 'ever closer union': Narrative framing in national news medias and resistance to EU integration. Eastern Journal of European Studies, 6(1), pp. 123-135.

DE VREESE, C. \& KANDYLA, A. (2011). News media representations of a common EU foreign and security policy. A cross-national content analysis of CFSP coverage in national quality newspapers. Comparative European Politics, 9(1), pp. 52-75. DOI:10.1057/cep.2009.10

DIDIUGWU, I. F. (2014). The mass media and the challenges of regional integration in Africa. 5th European Conference on African Studies 'African dynamics in a multipolar world', pp. 710-751.

EILDERS, C. \& VOLTMER, K. (2003). Zwischen Deutschland und Europa. Medien \& Kommunikationswissenschaft, 51(2), pp. 250-270. DOI:10.5771/1615634x-2003-2-250

ERIKSEN, E. O. \& FOSSUM, J. E. (2000). Democracy in the European Union. Integration through deliberation? London / New York, Routledge.

FETOSHI, A. (2017). The role of media in European integration. Process Kosovo case. Journal of Mass Communication \& Journalism, 7(3), pp. 1-6. DOI: 10.4172/2165-7912.1000338

GALITSINA, D. A. (2017). Natsionalnyye osobennosti osveshcheniya voprosov evraziyskoy integratsii v SMI gosudarstv-uchastnikov EAES [National features of coverage of issues of Eurasian integration in the media of the EAEU member States.]. Filologicheskiye nauki. Voprosy teorii i praktiki, 1(67) in 2 parts. Part 2, pp. 17-21.

GERHARDS, J. (1993). Westeurop ische Integration und die Schwierigkeiten der Entstehung einer europ ischen ffentlichkeit. Zeitschrift fr Soziologie, 22(2), pp. 96-110.

HRADZIUSHKA, A., BYKOV, I., \& BAKHVALOVA, A. (2020). Local media and digital environment in the Republic of Belarus: Strategies to survive. Proceedings of the 2020 IEEE Communication Strategies in Digital Society Workshop, St. Petersburg, Russia, p. 12-14. DOI: https://doi.org/10.1109/ComSDS49898.2020.9101307

KALYUGA, A. A. (2016). Informatsionnaya politika v stranakh SNG [Information policy in CIS countries]. Nauka o cheloveke: Gumanitarnyye issledovaniya, 4(26), pp. 91-100. 
KEVIN, D. (2015). Europe in the media: A comparison of reporting, representation, and rhetoric in national media systems in Europe. Routledge.

LATZER, M. \& SAUERWEIN, F. (2006). Europ isierung durch Medien: Ans tze und Erkenntnisse der ffentlichkeitsforschung. Langenbucher W.R., Latzer M. (eds) Europ ische ffentlichkeit und medialer Wandel. VS Verlag fr Sozialwissenschaften. DOI: 10.1007/978-3-531-90272-2_1

LOHNER, J. (2011). Die Europ ische Union in der Regionalpresse: Inhalte und journalistische Praxis aktueller Berichtserstattung. LIT Verlag, pp. 38-44.

MANG'ERA, S. D. (2014). Media and regional integration: A case study of the East Africa community. University of Nairobi, Institute of Diplomacy and International Studies. Research project.

MENENDEZ ALARKON, A. V. (2010). Representation of the European Union: Comparing newspaper coverage in France, Spain, and the United Kingdom. International Journal of Communication, 4, pp. 398-415.

MESHKOVA, T. A., IZOTOV, V. S., DEMIDKINA, O. V., \& KOFNER, YU. K. (2019). EAES V menyayushchemsya geopoliticheskom kontekste: Prioritety mezhdunarodnogo sotrudnichestva [The EAEU in a changing geopolitical context: Priorities of international cooperation]. Bulletin of RUDN Ser. Politologiya, 21(1), pp. 7-33. DOI: 10.22363/2313-1438-2019-21-1-7-33.

OSAVELYUK, E. A. (2016). Rol sredstv massovoy informatsii v obespechenii informatsionnoy bezopasnosti Rossii na evraziyskom prostranstve [The role of mass media in ensuring information security of Russia in the Eurasian space]. Mezhdunarodnoye Sotrudnichestvo Evraziyskikh Gosudarstv: Politika. Ekonomika. Pravo, 3(8), pp. 93-105.

PFETSCH, B. (2008). Agents of transnational debate across Europe: The press in emerging European public sphere. Javnost The Public, 15(4), pp. 21-40.

PODDUBSKAYA, T. A. (2018). Mezhgosudarstvennaya teleradiokompaniya 'Mir' na informatsionnom prostranstve stran SNG [Interstate TV and radio company 'Mir' on the information space of the CIS countries]. Prepodavatel XXI vek, 2-2, pp. 260-270.

POLONSKA-KIMUNGUYI, E. \& KIMUNGUYI, P. (2011). The making of the Europeans: Media in the construction of pan-national identity. International Communication Gazette, 73(6), pp. 507-523. DOI:10.1177/1748048511412283

POPOV, S. YU. (2015). SMI kak instrument informatsionnoy politiki Soyuznogo gosudarstva Rossii i Belorussii. [Mass media as an instrument of information policy of the Union State of Russia and Belarus]. Gumanitarnyye, sotsialno-ekonomicheskiye i obshchestvennyye nauki, 3-1, pp. 101-105. 
STRUGOVETS, V. M. (2011). Informatsionnaya politika SNG: Vzglyad v proshloye, perspektiva na budushcheye. [Information policy of the CIS: A look into the past, a perspective on the future]. Vlast, 6, pp. 119-122.

TEMIRBULATOV, A. M. \& GURUSKIN, P. YU. (2013). Formirovaniye obshchego mass-media prostranstva i osobennosti informatsionnogo sotrudnichestva stran SNG. [Formation of a common mass-media space and features of information cooperation of the CIS countries]. Vestnik Sankt-Peterburgskogo universiteta. Yazyk i literatura, 4, pp. 185-188.

TETTEY, W. J. (2001). The media and democratization in Africa: Contributions, constraints and concerns of the private press. Media, Culture \& Society, 23(1), pp. 5-31. DOI: 10.1177/016344301023001001

TRIGA, V.\&VADRATSIKAS, K. (2016-2018). The impact of media representations of the EU and its policies on European identity. Department of Communication and Internet Studies, Cyprus University of Technology for the COHESIFY project.

VARTANOVA, E. L. (2014). Postsovetskiye transformatsii rossiyskikh SMI i zhurnalistiki [Post-Soviet transformations of Russian media and journalism]. Moscow, Mediamir.

VARTANOVA, E. L. (2019). Mediasistemy stran SNG: $K$ formirovaniyu edinogo informatsionnogo prostranstva [Media systems of the CIS countries: Towards the formation of a single information space]. Vestnik MAG, 2-3(62-63), pp. 26-27.

VENIDIKTOV, S. V. (2016). Evraziyskoye informatsionnoye prostranstvo: Unifikatsiya ili koordinatsiya? [Eurasian information space: Unification or coordination?]. Nauchnyy rezultat. Sotsialnyye i gumanitarnyye issledovaniya, 2(1) (7), pp. 60-65.

VIKHROVA, O. YU. (2020). SMI i informatsionnaya bezopasnost EAES [Mass media and information security of the EAEU]. Mediascope, 1. Available from: http:// www.mediascope.ru/2613. DOI: 10.30547/mediascope.1.2020.7 